\title{
Effect of piriformis injection on neuropathic pain
}

\author{
Piriformis enjeksiyonunun nöropatik ağrı üzerine etkisi
}

\section{Dana TERLEMEZ,' (D) Tülay ERÇALIK²}

\section{Summary}

Objectives: The aim of this study was to investigate the effect of a piriformis injection on neuropathic pain in patients with piriformis syndrome.

Methods: Thirty patients with unilateral hip and/or leg pain, a positive FAIR test (increased H-reflex latency with Flexion, Adduction and Internal Rotation), and a trigger point at the piriformis muscle were enrolled in this prospective study. All of the patients exhibited neuropathic pain scored according to the Douleur Neuropathique 4 (DN4) of $\geq 4$ for at least 6 months. All of the patients received $4 \mathrm{~mL}$ of lidocaine $2 \%+1 \mathrm{~mL}$ of betamethazone to the piriformis muscle under the guidance of ultrasound. The Numeric Rating Scale (NRS), DN4, and the painDETECT (PD) questionnaire were used for outcome assessment.

Results: A statistically significant improvement was seen in all scores $(p<0.001)$ when both first week and first month results were compared with the baseline values. Comparison of the first week results with those of the first month revealed a statistically significant improvement in only the NRS and PD scores $(p<0.001)$. The greatest improvement in all scores was seen in the first week after the injection. A mild increase was seen in all scores at the first month compared to the first week.

Conclusion: A piriformis injection was found to be effective for both somatic and neuropathic pain in piriformis syndrome patients. Long-term follow-up is needed in order to consider this option alongside other treatment alternatives, like botulinum toxin and myofascial release.

Keywords: Neuropathic pain; piriformis muscle syndrome; ultrasound.

\section{Özet}

Amaç: Piriformis sendromlu hastalarda uygulanan piriformis enjeksiyonunun hastalardaki nöropatik ağrı üzerine etkisini değerlendirmek.

Gereç ve Yöntem: Tek taraflı kalça ve/veya bacak ağrısı olan, FAIR testi pozitif ve piriformis kasında palpasyonla tetik nokta saptanan 30 hasta çalışmaya dahil edildi. Bu prospektif çalışmada, tüm hastaların Douleur Neuropathique 4 (DN4) skoru en az 6 aydır 4 veya üzerinde idi. Tüm hastalara ultrason eşliğinde piriformis kasına $4 \mathrm{ml}$ lidokain $2 \%+1$ ml betametazon enjekte edildi. Post-enjeksiyon 1. hafta ve 1. ayda hastalar değerlendirildi. Çalışmamızda, Numerik ağıı skalası (NAS), DN4, PainDETECT anketi (PDA) yöntemlerini kullandık.

Bulgular: Başlangıç değerlerine göre 1. hafta ve 1. ay sonuçları karşılaştırıldığında tüm skorlarda istatistiksel olarak anlamlı düzelme olduğu görüldü $(p<0,001)$. Birinci hafta ve 1. ay sonuçları karşılaştıııldığında istatistiksel anlamlı düzelme sadece NAS ve PDA skorlarında görüldü $(p<0,001)$. Tüm skorlarda en anlamlı azalma 1. Haftanın sonunda görüşmekle beraber; 1 . ay sonunda da hafif bir azalma devam etmekteydi.

Sonuç: Bu çalışmada piriformis enjeksiyonu hem somatik hem de nöropatik ağrı komponenti üzerine etkili bulundu. Uzun dönem takip içeren çalışmalara, özellikle botulinum toksin ve miyofasyal gevşetme gibi diğer tedavi yöntemlerine karar verme açısından, ihtiyaç vardır.

Anahtar sözcükler: Enjeksiyon; nöropatik ağrl; piriformis sendromu; ultrason.

\section{Introduction}

Piriformis syndrome (PS) is an underestimated cause of sciatic neuralgia. It was thought that sciatica mostly occurs due to degenerative changes of the lumbar region. PS was first described by Yeoman in 1928.[1]
The piriformis is a 'pear shaped' muscle which externally rotates the hip in knee extension. ${ }^{[2]}$ The sciatic nerve goes under the piriformis muscle in the gluteal region. Beaton et al. identified some anatomic variations of the close relationship between the piriformis muscle and sciatic nerve. ${ }^{[3]}$

'Department of Physical Medicine and Rehabilitation, Health Sciences University, Şişli Hamidiye Etfal Hospital, Health Research and Application Center, İstanbul, Turkey

${ }^{2}$ Department of Algology, Health Sciences University, Şişli Hamidiye Etfal Hospital, Health Research and Application Center, İstanbul, Turkey

Submitted (Başvuru tarihi) 05.02.2019 Accepted after revision (Düzeltme sonrası kabul tarihi) 15.05.2019 Available online date (Online yayımlanma tarihi) 28.06.2019

Correspondence: Dr. Rana Terlemez. Sağlık Bilimleri Üniversitesi, Şişli Hamidiye Etfal Hastanesi, Sağlık Araştırma ve Uygulama Merkezi, Fiziksel Tıp ve Rehabilitasyon Kliniği, İstanbul Turkey. 
The awareness of PS has increased with prior studies. Correct diagnosis is important because PS is a successfully treatable cause of sciatic neuralgia. PS has both somatic and neuropathic pain components. Somatic pain is commonly related to myofascial origin of PS. ${ }^{[4]}$ On the other hand, hypertrophic and inflamed piriformis leads to the trapping of the sciatic nerve. Mixed pain mechanisms are valid in this syndrome. Maybe chronic PS lead to increase central sensitization and activate the neuropathic pain pathways. In this study we aimed to investigate the effect of piriformis injection on neuropathic pain in patients with PS.

Medical agents such as nonsteroidal anti-inflammatory drugs, muscle relaxants and neuropathic pain agents are first choices in the treatment of PS. Stretching exercises and physical therapy modalities should be added. If conservative treatment methods fail, injections to the piriformis muscle should be done by various methods ${ }^{[5]}$ Injections can be adminstered by using ultrasound (US), electromyography, computed tomography or magnetic resonance imaging. US-guided injection techniques have been well defined in prior studies. ${ }^{[6-9]}$ Some studies have assessed the effectiveness of US-guided techniques; however, none followed up on patients for neuropathic component.

\section{Material Methods}

\section{Study design}

This prospective study was conducted in patients with PS in physical medicine and rehabilitation department of a research and training hosiptal. Informed consent was obtained for all patients in this study. All procedures were in accordance with the ethical standards and with the 1964 Helsinki Declaration and its later amendments.

\section{Study population}

Thirty patients $(n=30)$ diagnosed as PS with neuropathic pain were enrolled in this study between 02/01/2017-30/11/2017. Diagnosis was based on patient history and physical examination; including trigger point at the piriformis muscle and positive FAIR (flexion, adduction, internal rotation) test. We included the cases between the ages of 18 to 60 . Patients exhibiting neuropathic pain according to Douleur Neuropathique $4(D N 4) \geq 4$ ) for at least 6 months were included. DN4 questionnare was developed by

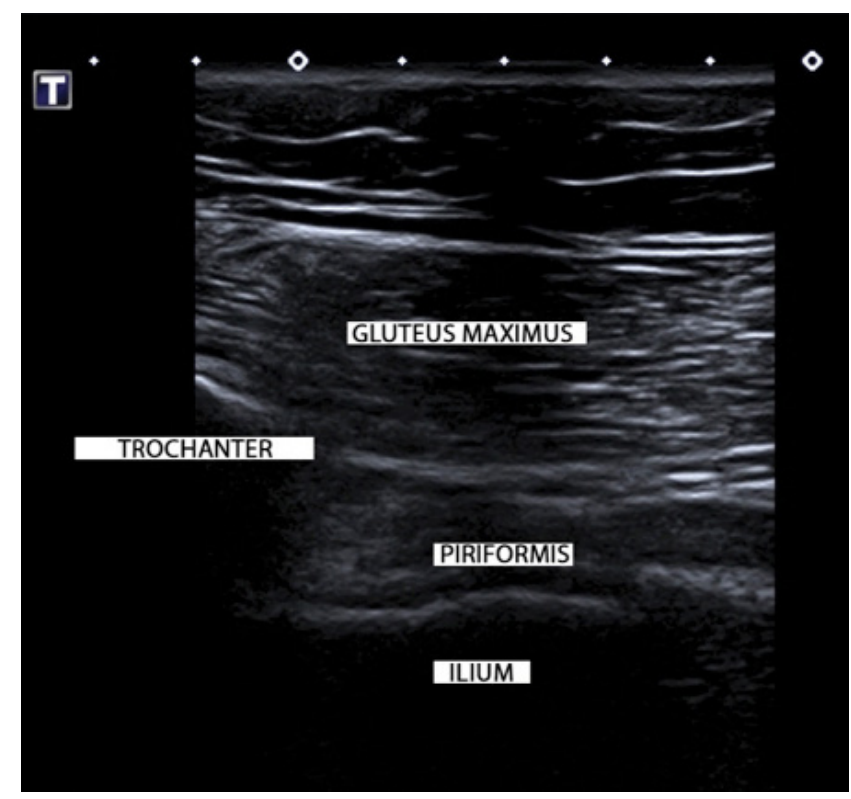

Figure 1. The piriformis muscle as a hyperecoic band under the gluteus maximus muscle.

the French Neuropathic Pain Group in 2005. ${ }^{[10]}$ The Turkish validity and reliability of the DN4 questionnare was made in 2010 with a sensitivity of $95 \%$ and a specifity of $96.6 \% .^{[1]}$

The exclusion criteria were having a history of the surgery at the lumbar region, restricted range of the hip or lumbar spine, existing neurological deficiency, active infectious disease or active psychiatric disease. Patients with a history of allergic reaction to the local anesthetics or current anticoagulant use were also excluded.

The mean Numeric Rating Scale (NRS), Douleur Neuropathique 4 (DN4), Pain Detect Questionnare (PDQ) were evaluated at baseline, 1.week and 1. month after the injection. PDQ was developed by Freynhagen et al. in 2006. ${ }^{[12]}$ PDQ is a simple, self-administered questionnaire which was adapted to Turkish language in 2013 by Alkan et al. ${ }^{[13]}$

\section{Injection technique}

All injections were done in prone position. After placing a linear US probe at transverse scan, first sacral hiatus was found. Then the US probe was moved towards the greater trochanter. The piriformis muscle was located as a hyperecoic band under the gluteus maximus muscle (Fig. 1). All patients received $4 \mathrm{ml}$ of lidocaine $2 \%+1 \mathrm{ml}$ of betametazone to the piriformis muscle in in-plane technique. All injections were performed by the same physiatrist. 
Table 1. Time-dependent changes in the scores

\begin{tabular}{lccc}
\hline & Mean & SD & p* $^{*}$ \\
\hline NRS-1 & 7.1 & 1.1 & \\
NRS-2 & 2.3 & 1.9 & $<0.001^{\mathrm{a}, \mathrm{b}, \mathrm{c}}$ \\
NRS-3 & 3.5 & 1.8 & \\
PDQ-1 & 22.3 & 4.0 & \\
PDQ-2 & 12.8 & 5.3 & $<0.001^{\mathrm{d}, \mathrm{e}, \mathrm{f}}$ \\
PDQ-3 & 15.0 & 5.2 & \\
DN4-1 & 5.1 & 0.9 & \\
DN4-2 & 2.5 & 1.4 & $<0.001^{\mathrm{g}, \mathrm{h}, \mathrm{i}}$ \\
DN4-3 & 2.7 & 1.5 & \\
\hline
\end{tabular}

SD: Standard deviation; NRS: Numeric rating scale; PDQ: Pain detect questionnare; DN-4: Douleur neuropathique 4; *Variance analyzes in recurrent measurements; ${ }^{\mathrm{a}, \mathrm{d}, \mathrm{g}}$ : Comparison of the first and second measurements NRS, PDQ, DN-4 (for all) $p<0.001 ;$;, , h: Comparison of the first and third measurements NRS, PDQ, DN-4 (for all) $p<0.001$; $c, \mathrm{f}, \mathrm{i}$ : Comparison of the second and third measurements NRS, PDQ, DN-4 (respectively) $p=0.001 ; p=0.009 ; p=0.326$.

\section{Statistical analysis}

The SPSS 20.0 software bundle was used to analyze the data. variance analysis was used in the analysis of recurrent measurements. Pearson correlation analysis was used for correlations. Statistical significance was set at $p<0.05$.

\section{Results}

Fourty-seven patients with PS were admitted to our clinic between 02/01/2017-30/11/2017. Thirty of them meeting the inclusion criteria were included in the study. The mean age of the patients was $52.7 \pm 11.6$. The mean duration of the symptoms was $10.9 \pm 7.8$. The study group was consisted of $20 \mathrm{fe}-$ male and 10 male patients.

When compared to the baseline scores significant decreases were seen in all measurements. The mean NRS scores at baseline, $1^{\text {st }}$ week and $1^{\text {st }}$ month were 7.1, 2.3 and 3.5 respectively. The mean DN4 scores at baseline, $1^{\text {st }}$ week and $1^{\text {st }}$ month were 5.1, 2.5 and 2.7 respectively. The mean PDQ scores at baseline, $1^{\text {st }}$ week and $1^{\text {st }}$ month were $22.3,12.8$ and 15 respectively. The highest decrease in all scores after injection was seen in the $1^{\text {st }}$ week. A mild increase was seen in all scores at the $1^{\text {st }}$ month compared to the $1^{\text {st }}$ week. However all scores were still lower than baseline scores (Table 1). In post hoc analyzes, when compared to the baseline results with both $1^{\text {st }}$ week and $1^{\text {st }}$ month results, statistically significant im-
Table 2. Correlation of NRS, PDQ and DN-4 scores for time-dependent changes

\begin{tabular}{|c|c|c|c|c|}
\hline & \multicolumn{2}{|c|}{ NRS* } & \multicolumn{2}{|c|}{ PDQ* } \\
\hline & $\mathbf{r}$ & $\mathbf{p}^{\ddagger}$ & $\mathbf{r}$ & $\mathbf{p}^{\ddagger}$ \\
\hline \multicolumn{5}{|c|}{ Baseline- $1^{\text {st }}$ week } \\
\hline PDQ & 0.657 & $<0.001$ & & \\
\hline DN-4 & 0.636 & $<0.001$ & 0.578 & 0.001 \\
\hline \multicolumn{5}{|c|}{ Baseline- $1^{\text {st }}$ month } \\
\hline PDQ & 0.617 & $<0.001$ & & \\
\hline DN-4 & 0.706 & $<0.001$ & 0.442 & 0.014 \\
\hline \multicolumn{5}{|c|}{$1^{\text {st }}$ week- $1^{\text {st }}$ month } \\
\hline PDQ & 0.698 & $<0.001$ & & \\
\hline $\mathrm{DN}-4$ & 0.697 & $<0.001$ & 0.636 & $<0.001$ \\
\hline
\end{tabular}

*The scores given represent the data of their own group; Pearson correlation analyzes.

provement were seen in all scores $(p<0.001)$. When compared to the $1^{\text {st }}$ week results with $1^{\text {st }}$ month results, statistically significant improvement were seen in only NRS and PD scores $(p<0.001)$.

When the correlation of the changes in NRS, PD and DN-4 scores were examined, a strong positive correlation was found between NRS and PD; also NRS and $\mathrm{DN}-4$. There was a moderate corralation between PD and DN-4 (Table 2).

\section{Discussion}

Pain in PS is usually characterized by two components; somatic and neuropathic. The somatic component is mostly related to myofascial origin while the neuropathic component is related to nerve compression or irritation. ${ }^{[14,15]}$ In this study we aimed to investigate the effect of piriformis injection on neuropathic pain in PS. Patients exhibiting neuropathic pain according to DN-4 for at least 6 months were included. When compared to the baseline scores significant decreases were seen in both $1^{\text {st }}$ week and $1^{\text {st }}$ month results for NRS, DN-4 and PD. We saw that the piriformis injection is effective not only on the somatic pain but also on neuropathic pain in PS.

The piriformis muscle originates from anterior part of the sacrum then passes through the greater sciatic notch and inserts to the medial aspect of the greater trochanter. The sciatic nerve usually passes through the greater sciatic notch below the pirifor- 
mis muscle. ${ }^{[3,16]}$ While there are still some uncertanities in etiologic factors of PM. This close relationship between the piriformis muscle and the sciatic nerve is the most accepted cause of sciatica in PS. Irritation of the fibular branch of the sciatic nerve commonly leads to pain or paresthesia in the posterior thigh or leg. We evaluated the symptom severity by using NRS, DN-4 and PD.

Neuropathic pain has a greater effect on quality of life of the patients and higher health care costs than the other types of pain. ${ }^{[17]}$ It requires different kind of assessment tools and treatment methods. ${ }^{[18,}{ }^{19]}$ PD and DN-4 are widely used and accepted questionnares for assessment of neuropathic pain. PD and DN-4 demonstrated a sensitivity of $85 \%$ and $83 \%$ and a specificity of $80 \%$ and $90 \%$ respectively, in some studies. ${ }^{[10,12]}$ Scores of all NRS, PD and DN-4 are positively correlated with each other supporting previous studies. In this studya strong positive correlation was found between NRS and PD; also NRS and DN-4. There was a moderate corralation between PD and DN-4. In a recent study Gudala et al. found good discriminant validity between PD and $\mathrm{DN}-4 .{ }^{[20]}$

There is still no definite diagnostic criteria for PS. Piriformis injection is an accepted method for both diagnosis and treatment. ${ }^{[8,9,21]}$ Steroid is a widely used medical agent for injection in PS and possitive effect of injection on somatic pain was shown in majority of the studies. ${ }^{[8,21-24]}$ Our study also showed the reduction in neuropathic pain scores. Because of the quick response to injection, it can be used as a diagnostic tool. But the effect of the duration is still remain unclear. In present study, the highest improvement in all scores after injection was seen in the $1^{\text {st }}$ week. A mild increase was seen in all scores at the $1^{\text {st }}$ month compared to the $1^{\text {st }}$ week. However all scores were still lower than baseline scores. It is our limitation that having a short follow-up period.

Botulinum toxin therapy is also be considered that could be effective for a longer period. Fishman et al. reported that 24 of the 27 patients had a good response to the botulinum toxin injection. ${ }^{[25]}$ Fishman et al. also showed that botulinum toxin provide more pain relief than other agents like steroids. ${ }^{[26]}$ But botulinum toxin therapy should not be considered as the first option in terms of cost effectiveness.

\section{Conclusion}

Injection for the piriformis syndrome with steroid, under the guidance of ultrasound was found to be effective for both somatic and neuropathic pain in this study. Long-term follow-up is needed for considering other treatment options like botulinum toxin or myofascial release.

\section{Conflict-of-interest issues regarding the authorship or article: None declared.}

\section{Peer-rewiew: Externally peer-reviewed.}

\section{References}

1. Yeoman WB. The relation of arthritis of the sacroiliac joint to sciatica: with an analysis of 100 cases. Lancet 1928;2:111922. [CrossRef]

2. G. Windisch, Braun EM, Anderhuber F. Piriformis muscle: clinical anatomy and consideration of the piriformis syndrome. Surg Radiol Anat 2007;29(1):37-45. [CrossRef]

3. Beaton $L E$, Anson BJ. The relation of the sciatic nerve and of its subdivisions to the piriformis muscle. Anat Rec 1937;70(1):1-5. [CrossRef]

4. Reus M, de Dios Berna J, Vazquez V, Redondo MV, Alonso J. Piriformis syndrome: a simple technique for US-guided infiltration of the perisciatic nerve. Preliminary results. Eur Radiol 2008;18(3):616-20. [CrossRef]

5. Kirschner JS, Foye PM, Cole JL. Piriformis syndrome, diagnosis and treatment. Muscie Nerve 2009;40(1):10-8. [CrossRef]

6. Huerto AP, Yeo SN, Ho KY. Piriformis muscle injection using ultrasonography and motor stimulation--report of a technique. Pain Physician 2007;10:687-90.

7. Chen $C P$, Shen $C Y$, Lew HL. Ultrasound-guided injection of the piriformis muscle. Am J Phys Med Rehabil 2011;90(10):871-2. [CrossRef]

8. Jeong HS, Lee GY, Lee EG, Joe EG, Lee JW, Kang HS. Longterm assessment of clinical outcomes of ultrasound-guided steroid injections in patients with piriformis syndrome. Ultrasonography 2015;34(3):206-10. [CrossRef]

9. Misirlioglu TO, Akgun K, Palamar D, Erden MG, Erbilir T. Piriformis syndrome: comparison of the effectiveness of local anesthetic and corticosteroid injections: a doubleblinded, randomized controlled study. Pain Physician 2015;18(2):163-71.

10. Bouhassira D, Attal N, Alchaar H, Boureau F, Brochet B, Bruxelle J, et al. Comparison of pain syndromes associated with nervous or somatic lesions and development of a new neuropathic pain diagnostic questionnaire (DN4). Pain 2005;114(1-2):29-36. [CrossRef]

11. Unal-Cevik I, Sarioglu-Ay S, Evcik D. A comparison of the DN4 and LANSS questionnaires in the assessment of neuropathic pain: validity and reliability of the Turkish version of DN4. J Pain 2010;11(11):1129-35. [CrossRef]

12. Freynhagen $R$, Baron R, Gockel U, Tölle TR. Pain DETECT: a new screening questionnaire to identify neuropathic com- 
ponents in patients with back pain. Curr Med Res Opin 2006;22(10):1911-20. [CrossRef]

13. Alkan H, Ardic F, Erdoğan C, Sahin F, Sarsan A, Fındıkoğlu $G$. Turkish version of the painDETECT questionnaire in the assessment of neuropathic pain: a validity and reliability study. Pain Medicine 2013;14(12):1933-43. [CrossRef]

14. Chen WS: Sciatica due to piriformis pyomyositis. Report of a case. J Bone Joint Surg 1992;74(10):1546-8. [CrossRef]

15. Sayson SC, Ducey JP, Maybrey JB, Wesley RL, Vermilion D. Sciatic entrapment neuropathy associated with an anomalous piriformis muscle. Pain 1994;59(1):149-52. [CrossRef]

16. Pecina M. Contribution to the etiological explanation of the piriformis syndrome. Acta Anat 1979;105(2):181-7.

17. Kleinman N, Patel AA, Benson C, Macario A, Kim M, Biondi DM. Economic Burden of Back and Neck Pain: Effect of a Neuropathic Component. Popul Health Manag 2014;17(4):224-32. [CrossRef]

18. Haanpää M, Attal N, Backonja M, Baron R, Bennett M, Bouhassira D,et al. NeuPSIG guidelines on neuropathic pain assessment. Pain 2011;152(1):14-27. [CrossRef]

19. Smith BH, Torrance N. Epidemiology of Neuropathic Pain and Its Impact on Quality of Life. Curr Pain Headache Rep 2012;16(3):191-8. [CrossRef]

20. Gudala K, Ghai B, Bansal D. Usefulness of four commonly used neuropathic pain screening questionnaires in patients with chronic low back pain: a cross-sectional study. Korean J Pain 2017;30(1):51-8. [CrossRef]

21. Jankovic D, Peng P, van Zundert A. Brief review: piriformis syndrome: etiology, diagnosis, and management. Can J Anaesth 2013;60(10):1003-12. [CrossRef]

22. Ozisik, Pinar Akdemir, et al. "CT-guided piriformis muscle injection for the treatment of piriformis syndrome."Turkish neurosurg 2014;24(4):471-7. [CrossRef]

23. Cassidy L, Walters A, Bubb K, Shoja MM, Tubbs RS, Loukas $M$. Piriformis syndrome: implications of anatomical variations, diagnostic techniques, and treatment options. Surg Radiol Anat 2012;34(6):479-86. [CrossRef]

24. Reus M, de Dios Berna J, Vazquez V, Redondo MV, Alonso J. Piriformis syndrome: a simple technique for US-guided infiltration of the perisciatic nerve. Preliminary results. Eur Radiol 2008;18(3):616-20. [CrossRef]

25. Fishman LM, Konnoth C, Rozner B. Botulinum neurotoxin type $B$ and physical therapy in the treatment of piriformis syndrome: A dose-finding study. Am J Phys Med Rehabil 2004;83(1):42-50. [CrossRef]

26. Fishman LM, Anderson C, Rosner B. Botox and physical therapy in the treatment of piriformis syndrome. Am J Phys Med Rehabil 2002; 81(12):936-42. [CrossRef] 